\title{
Evaluation of Asa River Water in Ilorin, Kwara State, Nigeria for Available Pollutants and their Effects on Mitosis and Chromosomes Morphology in Allium cepa Cells
}

\author{
*1'AKINBORO, A; ${ }^{1}$ PETER, NA; ${ }^{2}$ RUFAI, MA; ${ }^{3}$ IBRAHIM, AO \\ ${ }^{1}$ Department of Pure and Applied Biology, Ladoke Akintola University of Technology, P.M.B. 4000, Ogbomoso, Oyo State, Nigeria \\ ${ }^{2}$ Department of Zoology, College of Science, Engineering and Technology, Osun State University, Osogbo, Nigeria \\ ${ }^{3}$ Department of Pure and Applied Chemistry, Ladoke Akintola University of Technology, P.M.B. 4000, Ogbomoso, Oyo State, Nigeria \\ *Corresponding Author Email: aakinboro@lautech.edu.ng
}

\begin{abstract}
This study evaluated water samples from Asa River in Kwara state, Nigeria, for cytogenotoxicity at $25.0 \%, 50.0 \%, 100.0 \%$ following the Allium cepa assay. Onions were grown in the water samples for microscopic and macroscopic screenings. Heavy metals and volatile organic pollutants in the water were elucidated using AAS and GCMS techniques. The Water samples except the sample ' $\mathrm{C}$ ' induced higher mitotic index (MI) than the negative control. Root growth was significantly promoted at $25.0 \%$, and significantly reduced at $50.0 \%$ and $100.0 \%$ of the sample ' $\mathrm{C}$ ' and $100.0 \%$ of the sample ' $A$ '. Water sample ' $\mathrm{A}$ ' $(100.0 \%)$ induced highest percentage chromosomal aberrations (CA) while the water samples ' $\mathrm{B}$ ' and ' $\mathrm{C}$ ' induced higher percentage $\mathrm{CA}$ than the negative control. Cadmium was detected at a concentration higher than its permissible limit in drinking water. Poly aromatic hydrocarbons, Aromatic amines, Acridine dye, Phenolic and Polychlorinated compounds were detected in the water sample. The observed proliferative, inhibitory, cytotoxic and genotoxic effects of the water samples on A. cepa cells suggest that Asa river was polluted, having potential to adversely affect humans, animals and plants utilizing it along its course.
\end{abstract}

DOI: https://dx.doi.org/10.4314/jasem.v25i1.17

Copyright: Copyright (C) 2021 Akinboro et al. This is an open access article distributed under the Creative Commons Attribution License (CCL), which permits unrestricted use, distribution, and reproduction in any medium, provided the original work is properly cited.

Dates: Received: 02 October 2020; Revised: 26 November 2020; Accepted: 12 December 2020

Keywords: Allium cepa; Asa River; cytogenotoxicity; Nigeria; pollutants

Pollution of surface water source occurs through release of industrial, agricultural and domestic wastes into water body (Guan et al., 2017). Contamination and pollution of aquatic environment has become a serious matter of concern globally due to loss of aquatic biodiversity (Hussein et al., 2016). Chemical compounds from different sources into water body were cytotoxic, mutagenic and genotoxic (Pellacani et al., 2016). Therefore, it is important that freshwater sources are regularly screened to ensure that drinking water and agricultural products being irrigated with water from these sources are free of contaminants and pollutants that might find their way into water body through series of anthropogenic activities. Asa river supplies water to majority of people of Ilorin and assessment of quality of this water body is necessary to ensure that its use for different purposes is not associated with adverse effects in humans, animals and plants (Balogun and Ganiyu, 2017). Allium cepa is one of the higher plants employed as an excellent genetic model for assessing cytogenotoxic effects of environmental contaminants and pollutants on eukaryotic cells due to its good chromosomes condition characterized by large metacentric chromosomes (Leme and Marin-Morales, 2009). Interestingly, it produces comparable results with that from animal genetic assays. It can be used to screen cytogenotoxicity of single and complex chemicals (Bhat et al., 2017). Allium cepa assay was employed to evaluate cytogenotxicity of Sungai Dua river water in Pulau Pinang, Malaysia and Guaribas river water in Piauí, Brazil (Akinboro et al., 2011c; de Castro e Sousa et al., 2017). Previous studies on cytogenotoxicity of heavy metals and their accumulation in the organs of some selected fish species in Asa river water body and Apodu reservoir in Malete, Ilorin, Kwara State, Nigeria employed micronucleus assay and Ames test which can detect only clastogenic effect and point mutations caused by the environmental contaminants in this water body (Anifowose et al., 2018). This present study was undertaken on Asa River to screen for potential cytotoxic and genotoxic effects of its available chemicals contaminants / pollutants following the Allium cepa assay, and their identification using the AAS and GC-MS techniques.

\section{MATERIALS AND METHODS}

Collection of water samples: Water samples were collected strategically from three sampling points; Point ' $A$ ' which was close to a refuse dump site at the riverbank, point ' $\mathrm{B}$ ' which was $500 \mathrm{~m}$ away from point

*Corresponding Author Email: aakinboro@lautech.edu.ng 
$A$, point ' $C$ ' which was $500 \mathrm{~m}$ away from point $\mathrm{B}$, and this was where farmers who have farms along the riverbank usually pump water to irrigate their farmlands (Plate 1). The collected water samples were kept in 4 liters capacity clean glass bottles stored at $4^{\circ} \mathrm{C}$ until further analyses.
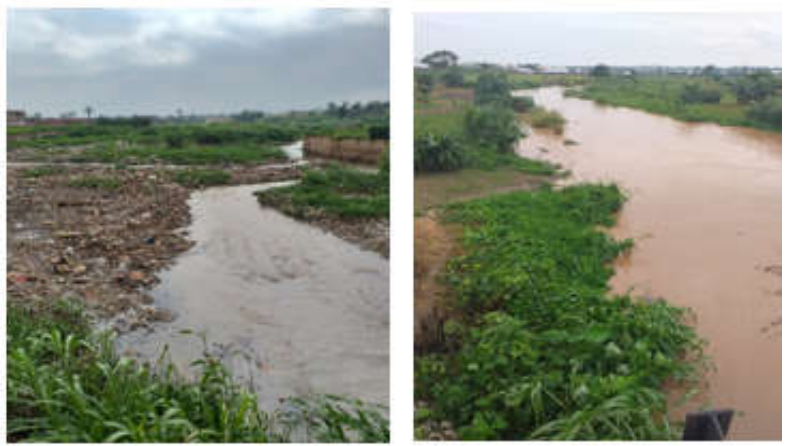

Plate 1: Sampling point A

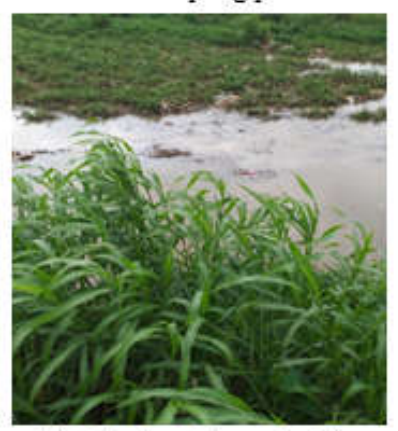

Plate 1: Sampling point $\mathrm{C}$

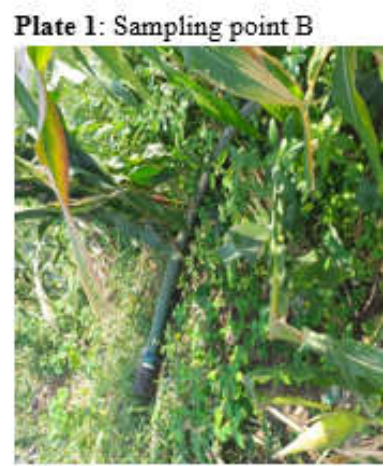

Plate 1: Irrigated maize farm wi Water from point $\mathrm{C}$

Plate 1: Water sampling points in Asa River water body

Allium cepa Assay: Onions were commercially purchased, sun dried for 1 week and further treated as described previously (Akinboro et al., 2011a). Absolute water sample 'A', 'B', and ' $\mathrm{C}$ ' was diluted to $25.0 \%$ and $50.0 \%$ using borehole water. The negative and positive controls were borehole water and $0.1 \%$ hydrogen peroxide, respectively. Ten onions were planted on each water sample in $100 \mathrm{ml}$ capacity beakers and placed in a cupboard for 48 hours and 72 hours for microscopic and macroscopic evaluations, respectively (Akinboro et al., 2011b). Root tips from four onions were cut and fixed in ethanol acetic acid fixative (3:1) after 48 hours. Slides were prepared, observed and scored under light microscope (CH-China) using oil immersion objective lens (Akinboro et al., 2017). Root lengths from the remaining onions were measured to determine toxicity of the water samples to $A$. cepa roots growth (Akinboro and Bakare, 2007; Verma and Srivastava, 2018).

Heavy metals analysis: Fifty milliliters of the water sample was added with $5 \mathrm{ml}$ nitric acid and the mixture was subjected to heat for complete digestion (Mahugija, 2018; Aloke et al., 2019). The digested solution was filtered (through a Whatman ${ }^{\circledR}$ filter paper, No 1, Qualitative Circles $110 \mathrm{~mm} \varnothing$, Cat No 1001 110) into a $50 \mathrm{ml}$ conical flask, and the filtrate was diluted with deionized water up to the calibrated line (Wold et al., 2016). The analysis of the diluted filtrate for Cadmium $\left(\mathrm{Cd}^{+2}\right)$, Copper $\left(\mathrm{Cu}^{+2}\right)$, Nickel $\left(\mathrm{Ni}^{+2}\right)$, Zinc $\left(\mathrm{Zn}^{+2}\right)$, Lead $\left(\mathrm{Pb}^{+2}\right)$, Manganese $\left(\mathrm{Mn}^{+2}\right)$ and Iron $\left(\mathrm{Fe}^{+2}\right)$ was carried out using each of the standards of the heavy metals to determine their concentration in the water sample using an autosampler Atomic Absorption Spectrophotometer (Agilent technology, Series A, USA). The reading was taken in triplicate, and the mean concentration of each heavy metal was recorded.
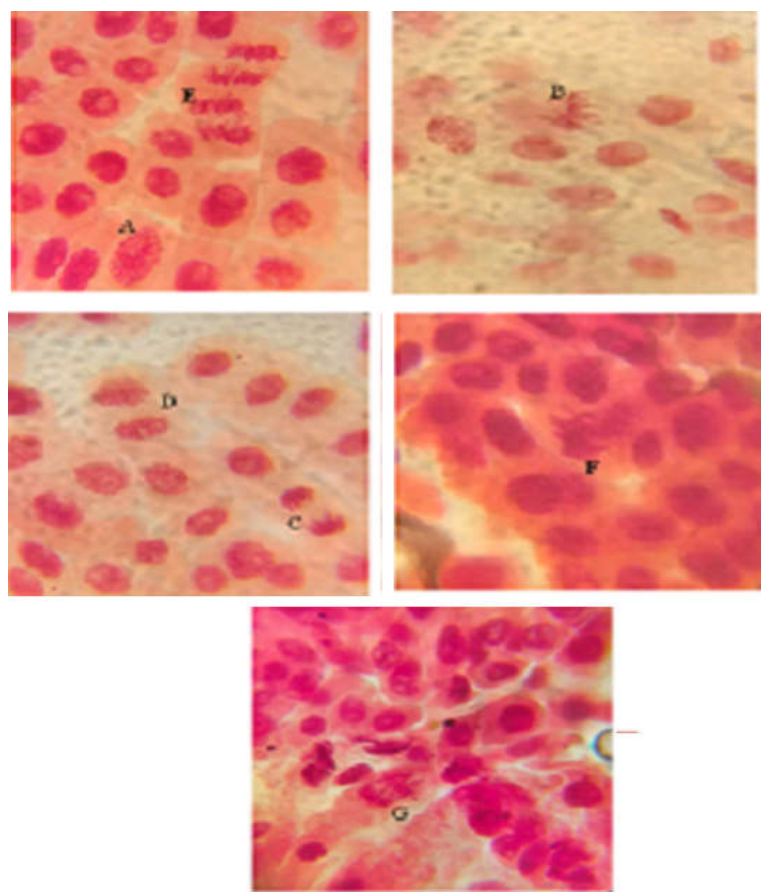

Plate 2: $\mathrm{A}=$ prophase; $\mathrm{B}=$ metaphase $\mathrm{C}=$ anaphase $\mathrm{D}=$ telophase; $\mathrm{E}=$ disturbed spindle $\mathrm{F}=$ sticky chromosome; $\mathrm{G}=$ anaphase bridge.

Gas chromatography- Mass spectroscopy (GC-MS) analysis: The volatile organic chemical compounds in the water sample were extracted by successive liquidliquid extraction using analytical grade n-hexane solvent. The water sample was subjected to Gas Chromatography coupled with Mass Spectrometer (Agilent Technologies, Model GC7890A/5975MS, USA). The analysis was performed using ultra inert GC capillary column $30 \mathrm{~m} \times 0.53 \mathrm{~mm}$ I.D., $5.0 \mu \mathrm{m}$ film thickness (Hewlett Packard, Palo Alto, USA) following the standardized protocol previously described (Akinboro et al., 2012; Bell et al., 2020). Individual chemical components in the water sample 
were identified compared with the NIST Library and the percentage match of the identified chemicals was recorded.

Statistical analysis: The obtained data were summarized and mean values were compared with the negative control using Duncan multiple range comparison in one way ANOVA of SPSS (version 17.0). Significantly different value was considered at $\mathrm{P}<0.05$.

\section{RESULTS AND DISCUSSION}

The mitotic index (MI) value at $100.0 \%$ of the water sample 'A' was $1.70 \%$ which was significantly higher $(\mathrm{P}<0.05)$ than the MI value of $1.40 \%$ induced by the negative control. Water sample ' $\mathrm{B}$ ' also induced higher MI value of $1.50 \%$ at the selected concentrations, but not significantly different from that induced by the negative control $(\mathrm{P}>0.05)$. The water sample ' $\mathrm{C}$ ' had $\mathrm{MI}$ value of $1.40 \%$ at $25.0 \%$, and $1.0 \%$ and $0.9 \%$, respectively at $50.0 \%$ and $100.0 \%$. These were not significantly different from MI induced by the negative control, except at $100 \%$ (Table 1). Water samples ' $A$ ', 'B', and ' $C$ ' induced normal stages of mitosis and different types of chromosomal aberrations (CA) namely; disturbed spindle, bridge anaphase and sticky metaphase (Plate 2). Highest and significantly different $C A$ of $2.2 \%$ was induced at $100.0 \%$ of the water sample ' $\mathrm{A}$ ' $(\mathrm{P}<0.05)$ (Table 1). Effects of the water samples on root growth of $A$. cepa showed that water sample ' $\mathrm{A}$ ' at $25.0 \%$ and $50.0 \%$ induced root lengths of $127.60 \%$ and $106.60 \%$ which were higher than that of the negative control, like was also recorded for the water samples ' $\mathrm{B}$ ' and ' $\mathrm{C}$ ' at $25.0 \%$ and $50.0 \%$ 'B'. However, there was inhibition of root growth to $90 \%$ by the absolute water sample ' $A$ ', at $50 \%$ of the sample ' $C$ ', and $100 \%$ of the samples ' $\mathrm{B}$ ' and ' $\mathrm{C}$ '. The root growth inhibitions caused by the water sample ' $C$ ' were significantly different from the negative control (Table 2).Cadmium $\left(\mathrm{Cd}^{+2}\right)$, Zinc $\left(\mathrm{Zn}^{+2}\right)$, Nickel $\left(\mathrm{Ni}^{+2}\right)$, Copper $\left(\mathrm{Cu}^{+2}\right)$, Manganese $\left(\mathrm{Mn}^{+2}\right)$, Lead $\left(\mathrm{Pb}^{+2}\right)$ and Iron $\left(\mathrm{Fe}^{+2}\right)$ were detected in the water sample in varied concentrations. Only $\mathrm{Cd}$ was detected at a higher concentration of $0.022 \mathrm{mg} / \mathrm{L}$ than its permissible limit of $0.003 \mathrm{mg} / \mathrm{L}$ in drinking water according to the WHO and EPA standards, while $\mathrm{Zn}, \mathrm{Mn}$ and Fe were lower than their permissible limits (Table 3). Twenty two different chemicals compounds belonging to 5 groups of aromatic compounds were detected. These include Polycyclic Aromatic Hydrocarbons (PAH), polychlorinated compounds, aromatic amines, phenolic compound and acridine dye. The percentage abundance of the detected chemical compounds in the water sample ranged between $12-43 \%$ (Table 4).
Induction of significantly higher mitotic index (MI) value at $100.0 \%$ and non-significantly different but higher MI values recorded at $50.0,25.0 \%$ of the water sample ' $A$ ', and at all the tested concentrations of the water ' $\mathrm{B}$ ' compared to the negative control suggests non-cytotoxicity, but rather indicates proliferative potency of the water samples. Similarly, the water sample ' $C$ ' was not cytotoxic at $25.0 \%$ and $50.0 \%$ except at $100.0 \%$. The observed proliferative and cytotoxic effects of the water samples indicate that the water body was contaminated and polluted. Both the significant increase and decrease in MI values compared with the negative control are important indices in monitoring environmental pollution. This parameter reveals possibilities of the tested water samples to induce uncontrolled proliferation of cells, leading to tumour formation, or / and stunted growth in biological organisms having similar eukaryotic cells and genetic constituents with the $A$. cepa cells (Leme and Marin-Morales, 2009). Induction of significantly higher chromosomal aberrations (CA) such as disturbed spindle, bridged anaphase and sticky chromosomes than that recorded with the negative control further corroborates that Asa River water was contaminated or /and polluted.

Induction of these forms of chromosomal aberrations implies that the water body possesses clastogenic, aneugenic and severe genotoxic effects on $A$. сера cells. Interestingly, the obtainment of highest percentage of CA at $100.0 \%$ of the water sample ' $\mathrm{A}$ ' further confirms its toxic potential. The results of root length measurement corroborated the results of microscopic screening. The induction of smaller root lengths by the absolute water samples from points ' $A$ ', ' $\mathrm{B}$ ', and ' $\mathrm{C}$ ' than that of the negative control implied root growth inhibitory effect. However, induction of longer root lengths at lower concentrations of the water samples was in support of the proliferative activity of this water body, and further suggests its ability especially those from points ' $A$ ' and ' $B$ ' to induce uncontrolled proliferation of cells, while, significant reduction of root length caused by the water sample ' $C$ ' further suggests its phytotoxicity.

Our results in this study for the first time using the $A$. cepa genetic assay have further confirmed pollution of Asa river as previously reported in the studies on heavy metals accumulation in some species of fish and microorganisms (Hussein et al., 2016; Anifowose et al., 2019). It is now established that the use of polluted Asa river water to irrigate farmlands along the riverbank could cause stunted growth of crops based on the effects of the water sample ' $\mathrm{C}$ ' on $A$. cepa root growth. 
Table 1: Effects of water samples on mitosis in Allium cepa cells

\begin{tabular}{|c|c|c|c|c|}
\hline Concentration (\%) & $\begin{array}{l}\text { (Dividing cell } \\
\pm \mathrm{SD} \text { ) }\end{array}$ & $\begin{array}{l}\text { Mitotic } \\
\text { index }(\%)\end{array}$ & $\begin{array}{l}\text { (Chromosomal } \\
\text { aberration } \pm \text { SD) }\end{array}$ & $\begin{array}{l}\% \text { chromosomal } \\
\text { aberration }\end{array}$ \\
\hline \multicolumn{5}{|l|}{ Sampling point $A$} \\
\hline Negative control & $6.80 \pm 3.27^{a b}$ & 1.40 & $0.60 \pm 0.89^{2}$ & 0.6 \\
\hline Positive control & $4.80 \pm 3.03^{b}$ & 1.00 & $1.60 \pm 1.14^{\text {wh }}$ & 1.6 \\
\hline 25.0 & $7.80 \pm 2.78^{\text {ah }}$ & 1.60 & $1.60 \pm 1.14^{\text {sh }}$ & 1.6 \\
\hline 50.0 & $7.40 \pm 1.82^{\text {sh }}$ & 1.50 & $0.80 \pm 0.84^{\text {sh }}$ & 0.8 \\
\hline 100.0 & $8.60 \pm 2.70^{\circ}$ & 1.70 & $2.20 \pm 1.10^{b}$ & 2.2 \\
\hline \multicolumn{5}{|l|}{ Sampling point B } \\
\hline Negative control & $6.80 \pm 3.27^{a b}$ & 1.40 & $0.60 \pm 0.89^{2}$ & 0.6 \\
\hline Positive control & $4.80 \pm 3.03^{b}$ & 1.00 & $1.60 \pm 1.14^{\text {कh }}$ & 1.6 \\
\hline 25.0 & $7.60 \pm 1.52^{ \pm b}$ & 1.50 & $1.40 \pm 1.14^{a b}$ & 1.4 \\
\hline 50.0 & $7.40 \pm 1.67^{\text {ab }}$ & 1.50 & $1.20 \pm 1.10^{4 b}$ & 1.2 \\
\hline 100.0 & $7.40 \pm 2.07^{ \pm b}$ & 1.50 & $2.00 \pm 1.00^{4 b}$ & 2.0 \\
\hline \multicolumn{5}{|l|}{ Sampling point $\mathbf{C}$} \\
\hline Negative control & $6.80 \pm 3.27^{2 \mathrm{~b}}$ & 1.40 & $0.60 \pm 0.89^{a}$ & 0.6 \\
\hline Positive control & $4.80 \pm 3.03^{b}$ & 1.00 & $1.60 \pm 1.14^{\text {sh }}$ & 1.6 \\
\hline 25.0 & $6.80 \pm 3.27^{4 b}$ & 1.40 & $1.40 \pm 1.14^{4 b}$ & 1.4 \\
\hline 50.0 & $5.20 \pm 0.84^{\text {bb }}$ & 1.00 & $0.80 \pm 0.84^{-b}$ & 0.8 \\
\hline 100.0 & $4.40 \pm 2.07^{\mathrm{b}}$ & 0.90 & $0.80 \pm 0.84^{-b b}$ & 0.8 \\
\hline
\end{tabular}

Values of the measured parameters in the same column with different superscript letter (s) were significantly different $(\mathrm{P} \leq 0.05)$.

Table 2: Root lengths of Allium cepa grown in water samples from Asa River in Ilorin, Kwara state Nigeria

\begin{tabular}{|c|c|c|c|c|c|c|}
\hline \multirow[t]{2}{*}{ Concentration (\%) } & \multicolumn{2}{|c|}{ Sampling point $\mathrm{A}$} & \multicolumn{2}{|c|}{ Sampling point B } & \multicolumn{2}{|c|}{ Şampling point C } \\
\hline & Root length $(\mathrm{cm})$ & $\begin{array}{l}\% \text { root } \\
\text { growth }\end{array}$ & Root length $(\mathrm{cm})$ & $\begin{array}{l}\% \text { root } \\
\text { growth }\end{array}$ & Root length $(\mathrm{cm})$ & $\begin{array}{l}\% \text { root } \\
\text { growth }\end{array}$ \\
\hline Negative control & $4.10 \pm 1.51^{\mathrm{d}}$ & 100.00 & $4.10 \pm 1.51^{d}$ & 100.00 & $4.10 \pm 1.51^{\mathrm{d}}$ & 100.00 \\
\hline Positive control & $0.51 \pm 0.15^{r}$ & 12.44 & $0.51 \pm 0.15^{r}$ & 12.44 & $0.51 \pm 0.15^{r}$ & 12.44 \\
\hline 25.0 & $5.23 \pm 1.10^{\text {sh }}$ & 127.60 & $4.51 \pm 0.92^{c}$ & 110.00 & $5.03 \pm 0.76^{b}$ & 122.70 \\
\hline 50.0 & $4.37 \pm 0.75^{\text {cal }}$ & 106.60 & $5.54 \pm 0.73^{2}$ & 135.1 & $3.49 \pm 0.77^{t}$ & 85.10 \\
\hline 100.0 & $3.69 \pm 0.78^{t}$ & 90.00 & $4.05 \pm 0.87^{\mathrm{a}}$ & 98.8 & $3.37 \pm 0.66^{\circ}$ & 82.20 \\
\hline
\end{tabular}

Values that have the different superscript alphabet(s) in the same column are significantly different at $P<0.05$

Table 3: Heavy metals concentrations detected in water sample from Asa River in Ilorin, Kwara State

\begin{tabular}{llll}
\hline Heavy metals & $\begin{array}{l}\text { Concentration } \\
\text { detected }(\mathrm{mg} / \mathrm{L})\end{array}$ & $\begin{array}{l}\text { WHO limit } \\
(\mathrm{mg} / \mathrm{L})\end{array}$ & $\begin{array}{l}\text { USEPA } \\
\text { limit } \mathrm{mg} / \mathrm{L}\end{array}$ \\
\hline Cadmium $-\mathrm{Cd}$ & 0.022 & 0.003 & 0.003 \\
Zinc $-\mathrm{Zn}$ & 0.014 & 5.0 & $5.0-15.0$ \\
Nickel $-\mathrm{Ni}$ & -0.040 & 0.02 & $\mathrm{NA}$ \\
Copper $-\mathrm{Cu}$ & -0.091 & 1.0 & $0.05-1.5$ \\
Manganase $-\mathrm{Mn}$ & 0.089 & 0.1 & 0.5 \\
Lead $-\mathrm{Pb}$ & -0.120 & 0.05 & 0.02 \\
Iron $-\mathrm{Fe}$ & 0.028 & 0.30 & $\mathrm{NA}$ \\
\hline rld Health Organization; EPA $=$ Environmental Protection Agency; $\mathrm{NA}=$ Not available
\end{tabular}

The observed proliferative, root growth promoting and inhibitory, cytotoxic and genotoxic effects of the water samples might have been caused by the types and concentration of polycyclic aromatic hydrocarbons (PAH), aromatic amines, acridine dye, polychlorinated and phenolic compounds, and heavy metals detected in the water body.

These are well known cytotoxic and genotoxic agents causing mitotic inhibition and various kinds of chromosomal aberrations in $A$. cepa cells and different types of point mutations in the Ames Salmonella/microsome assay (Zeyad et al., 2019). Polycyclic aromatic hydrocarbons in the crude oil are the most dangerous environmental contaminants due to their harmful effects such as toxicity, mutagenicity and carcinogenicity on different living organisms.
Cadmium $\left(\mathrm{Cd}^{+2}\right)$, Zinc $\left(\mathrm{Zn}^{+2}\right)$, Manganase $\left(\mathrm{Mn}^{+2}\right)$ and Iron $\left(\mathrm{Fe}^{+2}\right)$ were previously detected in the water sample at various concentrations (Anifowose et al., 2019).

Mercury, $\mathrm{Cd}, \mathrm{As}, \mathrm{Pb}, \mathrm{Sb}, \mathrm{Cr}$, and $\mathrm{Sr}$ are very toxic even at low concentrations because they are nonbiodegradable leading to their bioaccumulation in the human body to cause damage to nervous system and internal organs (Ogunkunle et al., 2016). Heavy metals have been associated with mitotic inhibition and chromosomes abnormalities in A. cepa cells. They are toxic agents capable of causing DNA damage through interference with the enzymatic processes and DNA repair mechanism in exposed organisms (Matos et al., 2017). 
Table 4: Chemical compounds detected in Asa river water sample following the GC-MS technique

\begin{tabular}{|c|c|c|c|c|c|}
\hline Peak & $\begin{array}{l}\text { Retention } \\
\text { time } \\
\text { (min) }\end{array}$ & $\begin{array}{l}\% \\
\text { Area }\end{array}$ & Identified chemicals in the library & CASNO & $\begin{array}{l}\% \\
\text { Matcl }\end{array}$ \\
\hline 1 & 4.78 & 0.3594 & 2-Pyridinamine, 3,5-dibromo- & $035486-42$ & 22 \\
\hline 2 & 5.14 & 0.4813 & Phenol, 2,4-dibromo- & $000615-58$ & 22 \\
\hline 3 & 5.22 & 0.3779 & Methaqualone & $000072-44$ & 30 \\
\hline 4 & 5.38 & 0.9599 & 3,5-Di-t-butyl-4-methoxy-1,4-dihydrobenzaldehyde & $1000130-2$ & 35 \\
\hline 5 & 5.58 & 1.0294 & Pyrimidine, 5-bromo-2,4-bis(methylthio)- & $060186-81$ & 38 \\
\hline 6 & 5.63 & 0.3446 & $\begin{array}{l}\text { 1,2-Benzenedicarboxylic acid, 4-methyl-5-(1-methylethyl)-, } \\
\text { dimethyl ester }\end{array}$ & $055044-59$ & 35 \\
\hline 7 & 6.04 & 5.1461 & $\begin{array}{l}\text { 4-(4,5-Diphenyl-1H-imidazol-2-ylsufanyl)-3-oxo-2-(phenyl- } \\
\text { hydrazono)-butyric acid, ethyl ester }\end{array}$ & $1000318-3$ & 14 \\
\hline 8 & 6.12 & 4.1711 & Propionic acid, 3-bis(diethylphosphonatomethyl) amino- & $178762-71$ & 22 \\
\hline 9 & 6.27 & 1.3046 & Indan-1,3-dione, 2-(1,3-dimethyl-1H-pyrazol-4-ylmethylene)- & $1000316-7$ & 18 \\
\hline 10 & 6.41 & 2.0764 & Adamantane-2,6-dione, bis(ethylene ketal)- & 060797-89 & 25 \\
\hline 11 & 6.49 & 1.6541 & 4-Pyridinamine, 3,5-dibromo- & $084539-34$ & 18 \\
\hline 12 & 6.57 & 2.5341 & 3-(2-Hydroxy-6-methylphenyl)-4(3H)-quingzolinone & $052898-72$ & 22 \\
\hline 13 & 6.67 & 3.2984 & Cinnamic acid, $\mathrm{p}$-(trimethylsiloxy)-, methyl ester & $027798-69$ & 30 \\
\hline 14 & 7.35 & 1.2413 & $\begin{array}{l}\text { Pyridine-3-carbonitrile, 2-amino-4-(4-methoxyphenyl)-5- } \\
\text { methyl-6-propyl- }\end{array}$ & $1000264-8$ & 35 \\
\hline 15 & 7.41 & 2.9268 & 2-Ethylacridine & $055751-83$ & 15 \\
\hline 16 & 7.56 & 1.8615 & (2-Phenyl-1-benzimidazolyl)acetic acid & $092437-42$ & 27 \\
\hline 17 & 8.10 & 2.7038 & lH-Indole, 3-(2-methoxyethyl)-2-(2-pyridyl)- & $161988-60$ & 43 \\
\hline 18 & 8.89 & 2.7248 & $\begin{array}{l}\text { 2,6-Pyridinecarboxylic acid, hexyl 3-(2-methoxyethyl)nonyl } \\
\text { ester }\end{array}$ & $1000369-2$ & 25 \\
\hline 19 & 10.11 & 1.109 & $\begin{array}{l}\text { Benzothiophene-3-carboxamide, } 4,5,6,7 \text {-tetrahydro-2amino- } \\
\text { 6-tert-butyl- }\end{array}$ & $1000272-8$ & 22 \\
\hline 20 & 11.10 & 0.8412 & Phenol, 2,4-dibromo-, acetate & $036914-79$ & 12 \\
\hline 21 & 12.18 & 0.6695 & Benzene, 1,2,3,5-tetrachloro-4,6-difluoro- & $001198-56$ & 22 \\
\hline 22 & 12.78 & 0.9187 & 1,2-Bis(trimethylsilyl) benzene & $017151-09$ & 15 \\
\hline
\end{tabular}

Apart from the refuses dumped at the riverbank of Asa River, fertilizer and pesticide application by farmers along the riverbank may be the source of heavy metals into the water body (Aliyu et al., 2017). The concentration of $\mathrm{Cd}$, higher than its permissible limit in drinking water according to the WHO and USEPA standards further implies that the water body was polluted and unfit for consumption in any form. High concentration of $\mathrm{Cd}$ in water sources could be possibly due to the waste disposal method, natural processes, human /anthropogenic activities, agricultural practices, closeness of the water body to roads with high traffic density, metal melting and electroplating, coal refining and oil fired power stations (Aloke et al., 2019). Environmental exposure to $\mathrm{Cd}$ at a high concentration is injurious to health as it can cause kidney and bone damages, neurotoxicity (Oluyemi and Olabanji, 2011; Chaitali and Jayashree, 2013).

Conclusion: These observed effects of the water samples on A. cepa cells in this study suggest that Asa river was polluted, and its use as drinking water sources and to irrigate farmlands may be associated with adverse effects in human, animals and plants that utilize it. For the first time, our results have suggested the possible effects of this water body on plant cells including its potential to cause different types of chromosomal aberrations using the $A$. cepa assay.

\section{REFERENCES}

Akinboro, A; Bakare, AA (2007) Cytotoxic and genotoxic effects of aqueous extracts of five medicinal plants on Allium cepa Linn. $J$. Ethnopharmacol. 112: 470-475.

Akinboro, A; Kamaruzaman, BM; Mohd Zaini, A; Othman, AS (2011a) Mutagenic and antimutagenic potentials of fruit juices of five medicinal plants in Allium cepa L.: Possible influence of DPPH free radical scavengers. Afr. $J$. Biotech. 10(51): 10520-10529.

Akinboro, A; Kamaruzaman, BM; Mohd Zaini, A; Shaida, FS; Othman, AS (2011b) Antioxidants in aqueous extract of Myristica fragrans (Houtt.) suppressed mitosis and cyclophosphamideinduced chromosomal aberration in the Allium cepa L. cell. J. Zheijang Univ. Sci. B, 12(11): 915-922.

Akinboro, A; Kamaruzaman, M; Selestin, R; Vijay, RM (2011c) Genotoxicity assessment of water samples from the sungai dua river in Pulau Pinang, Malaysia, using the Allium cepa test. Trop. Life Sci. Res. 22(2): 23-35.

Akinboro A., Kamaruzaman B.M., Mohd Zaini A., Ahmad S.O., Tang H.Y., Siti Marina M. (2012) 
Mutagenic and antimutagenic assessment of methanol leaf extract of Myristica fragrans (Houtt.) using in vitro and in vivo genetic assays. Drug Chem Toxicol, 35(4): 412-422.

Akinboro, A; Adedosu, OT; Famurewa, FO; Olowe, T; Oyewole, OO. (2017) Antioxidant, Proximate and Cyto-genotoxic Evaluation of Anti-typhoid Fever Herbal Recipe in Allium cepa Cells. Global J. Bio. Sci. Biotech. 6 (1): 24-29.

Aliyu, TH; Balogun, OS; Namani, CS; Olatinwo, LK; Aliyu, AS. (2017) Assessment of the presence of metals and quality of water used for irrigation in Kwara State, Nigeria, Pollution, 3(3): 461-470.

Aloke, C; Uzuegbu, IE; Ogbu, PN; Ugwuja, EI; Orinya, OF; Obasi, IO. (2019) Comparative assessment of heavy metals in drinking water sources from Enyigba Community in Abakaliki Local Government Area, Ebonyi State, Nigeria. Afr. J. Environ. Sci. Tech. 13(4): 149-154.

Anifowoshe, AT; Oladipo, SO; Owolodun, OA; Akinseye, MK; Olafimihan, TF; Sidiq, AG; Muhammed, AA; Asa, TA; Mustapha, MK. (2018) Ecogenotoxicogical assessments of some selected fish species from Apodu Reservoir, Malete, North Central, Nigeria, Manila J. Sci. 11: $1-14$.

Anifowoshe, TA; Oladipo, SO; Adebayo, OM; Eboh, OS; Abdussalam, AR; Adegbenro, AM; Ojo, TI; Adetunji, AK; Yekeen, OH; Adebiyi, AK; Tijani, OS; Oladipupo, OR; Abdulkareem, IS. (2019) Induction of Micronuclei, Base-pair Substitution Mutation and Excision-repair Deficient by Polluted Water from Asa River in Nigeria. Ann. Sci. Tech. 4 (2): 68-77

Balogun, OS; Ganiyu, HO. (2017) Study and analysis of Asa river hypothetical dam break using HecRas. Niger. J. Technol. (NIJOTECH) 36: $315-$ 321.

Bell, AM; Baier, R; Kocher, B; Reifferscheid, G; Buchinger, S; Ternes, T. (2020) Ecotoxicological characterization of emissions from steel coatings in contact with water. Water Res. 173: 115525.

Bhat, SA; Singh, J; Singh, K; Vig, AP. (2017) Genotoxicity monitoring of industrial wastes using plant bioassays and management through vermitechnology: A review. Agric. Nat. Resource, 51: 325-337.
Chaitali, VM; Jayashree, D. (2013) Review of heavy metals in drinking water and their effect on human health. Int. J. Innov. Res. Sci. Engr. Technol. 2: 7.

de Castro e Sousa, JM; Peron, AP; da Silva e Sousa, L; de Moura Holanda, M; de Macedo Vieira Lima, A; de Oliveira, VA; da Silva, FCC; de Moris Lima, LHG; Matos, LA; de Moura Dantas, SMM; de Aguiar, PS; Islam, MT; de Carvalho Melo-Cavalcante, AA; Bonecker, CC; Julio Junior, HF. (2017) Cytotoxicity and genotoxicity of Guaribas river water (Piauí, Brazil), influenced by anthropogenic action. Environ. Monitor. Assess. 189: 301 .

Guan, Y; Wang, X; Wong, M; Sun, G; An, T; Guo, J; Zhang, G. (2017) Evaluation of Genotoxic and Mutagenic Activity of Organic Extracts from Drinking Water Sources. PLoS ONE, 12(1): 0170454

Hussein, KO; Iyiola, OA; Simon, I; Oladipo, SO. (2016) Determination of Heavy Metal Genotoxicity and their Accumulation Pattern in Different Fish Organs of Selected Fish Species collected from the Asa River, Ilorin, Kwara State, Nigeria, J. Appl. Sci. Environ. Mgt. 20 (3): 735745 .

Leme, DM; Marin-Morales, MA. (2009) Allium cepa test in environmental monitoring: A review on its application. Mut. Res. / Rev. Mut. Res. 682: 7181.

Mahugija, JAM. (2018) Levels of heavy metals in drinking water, cosmetics and fruit juices from selected areas in Dar Es Salaam, Tanzania, Tanz. J. Sci. 44(1): 1-11.

Matos, LA; Cunha, ACS; Sousa, AA; Maranhoa, JPR; Santos, NRS; de, MC; Gonçalves, M; de, M; Dantas, SMM; de C e Sousa, JM; Peron, AP; da Silva, FCC; de Alencar, MVOB; Islam, Md T; de Aguiar, RPS; de C.Melo-Cavalcante, AA; Bonecker, CC; Junior, HFJ. (2017) The influence of heavy metals on toxicogenetic damage in a Brazilian tropical river. Chemosphere. 185: 852859.

Ogunkunle, CO; Kamaldeen, M; Stephen. O; Paul, OF. (2016) Assessment of metallic pollution status of surface water and aquatic macrophytes of earthen dams in Ilorin, north-central of Nigeria as indicators of environmental health. J. King Saudi Univ. Sci. 28: 324-331. 
Oluyemi, EA; Olabanji, IO. (2011) Heavy metals determination in some species of frozen fish sold at Ile-Ife main Market, South West Nigeria. Ife J. Sci. 13(2):355-362.

Pellacani, C; Cassoni, F; Bocchi, C; Martino, A; Pinto, G; Fontana, F; Furlini, M; Buschini, A. (2016) Cyto- and genotoxic profile of groundwater used as drinking water supply before and after disinfection. $J$. water health 14(6): 901-913.

Verma, S; Srivastava, A. (2018) Morphotoxicity and cytogenotoxicity of pendimethalin in the test plant Allium cepa L. - A biomarker based study, Chemosphere, 206:248-254.
Wold, FG; Ayenew, B; Ahmad, T. (2016) Assessment of heavy metals concentration in Togona River of Goba Town, Oromia Region, Ethiopia, Int. J. Chem. Sci. 14(4):3207-3214.

Zeyad, MT; Kumar, M; Malik, A. (2019) Mutagenicity, genotoxicity and oxidative stress induced by pesticide industry wastewater using bacterial and plant bioassays, Biotechno. Rep. 24: e00389. 